\title{
Knowledge, Attitude and Acceptability of Premarital Genetic Services for Sickle Cell Disease among Undergraduates of a Nigerian Private Tertiary Institution
}

\author{
Article by Olufisayo. A Bademosi ${ }^{1}$, Titilayo Olaoye ${ }^{2}$, Saratu. O Ajike ${ }^{3}$ \\ 1, 2, ${ }^{3}$ Department of Public Health School of Public \& Allied Health, Babcock \\ University, Ilishan-Remo, Ogun state, Nigeria. \\ ${ }^{3}$ Email: suo2009@gmail.com
}

\begin{abstract}
In Nigeria annually, 150,000 children are born with sickle cell anemia. One way of preventing sickle cell disease is through premarital genetic counseling and screening. This study therefore assessed the knowledge, attitude and acceptability of premarital genetic services for sickle cell disease among Babcock University Undergraduates.

The study was descriptive and cross sectional in design. Three hundred and seventy seven respondents were randomly selected using multistage sampling technique. Data was collected using a validated semi-structured questionnaire that was self-administered with a CronbachAlpha test of 0.747. It was analyzed using the statistical package for social science (SPSS) version 21 to generate descriptive and inferential statistics.

The results showed that more than half 229 (60.7\%) of the respondents were females while $148(39.3 \%)$ of the respondents were males. Three hundred and fifteen of the respondents were between the age range of 16-20 years with the mean age of 18.99 and $S D \pm 0.107 .363$ (96.3\%) of respondents had heard of sickle cell diseasewhile, 229 (60.7\%) agreed that intending couples should attend premarital genetic services and thus showed positive attitude. Another 350 (92.8\%) of the respondents would undergo premarital genetic services if it is available. There is a significant difference between knowledge and acceptability of respondents towards premarital genetic services $(P=0.047)$

In conclusion, the respondents had a high level of knowledge and acceptability on premarital genetic services and sickle cell disease. All sectors should increase efforts in creating awareness about premarital genetic services and locations.
\end{abstract}

Keywords: Premarital, genetic services, Knowledge, Acceptability, Attitude, sickle cell anemia

\section{Introduction}

Screening before a marital union may be considered as a more important measure for primary prevention, than neonatal screening which serves as secondary or tertiary prevention (Tamhankar et al, 2009). This is especially true for intending couples. Healthy marriage is defined as "state of agreement and harmony between the marriage partners with regard to the healthy, psychological, sexual, social, and legislative aspects, aiming at making a sound family and begetting healthy, happy children." Hereditary or contagious diseases can disturb this "happy life" leading to psychological, social and economic problems as well as medical complications with their reflection on the patient, family and society (Ministry of Health Portal, Kingdom of Saudi Arabia, 2014).

The commonest hereditary disease in Africa has been identified as sickle cell disease (WHO, 2011). In Nigeria, Sickle cell anemia remains a public health problem. Twenty-four percent of the population are carriers of the mutant gene and the prevalence of sickle-cell anaemia is about 20-30 per 1000 births (WHO, 2006).Sickle cell disease is a term used for a group of conditions in which the red blood cells have an abnormal type of haemoglobin called haemoglobin S (Anie, 2010). This disease occurs due to the inheritance of the mutant haemoglobin genes from both parents (Moronkola et al, 2007). Sickle-cell disease also has 
major psychological, social and economic implications for the affected child as well as the family (Anie, 2010).

Sickle cell disease can only be cured by bone marrow transplant also known as stem cell transplant. It is a very expensive treatment and involves replacing the affected bone marrow with bone marrow transplanted by someone without sickle cell disease. This is not feasible in low income countries (Owolabi et al, 2011). Therefore, for Africans and in particular Nigerians, an important and cost effective approach for controlling the disease is preventionand this depends upon the detection of carriers, genetic counseling, prenatal screening for fetal genotype in couples who are both carriers and newborn screening for sickle cell genotype (Owolabi et al, 2011).

Recent reports showed that Nigeria alongside India, and the Democratic Republic of the Congo [DRC] contributed $57 \%$ of the global total of newborns with sickle cell anemia. The contributions of the two lattercountries have been projected to decrease by 2050, but the contribution of Nigeria has been projected to increase from the present $30 \%$ to $35 \%$ by 2050 (Piel, Hay, Gupta, Weatherall, \&Williams, 2013). This calls for the urgent introduction of premarital genetic services in Nigeria, to bring down the projected increase. Moreover, religious and cultural beliefs of people regarding the origin of sickle cell disease and its treatment are drawbacks. There is still a palpable lack of information about the disorder which, with the increasing prevalence, has encouraged the growth of myths, misinformation, inappropriate treatment, frustration and stigmatization (Diallo, \& Tchernia, 2007).

Tertiary institutions in Nigeria usually comprise mainly of youths who are unmarried and intend to get married and procreate in future. Many university students do not view sickle cell anaemia and genotype incompatibility as issues to be considered in making marital decisions and therefore might be willing to proceed with marriage in such circumstances (Alao\&Nwannadi, 2009). This study therefore sought to find out if undergraduates are knowledgeable, have a very positive attitude and high acceptability of these premarital genetic services available for the prevention of sickle cell disease. The information obtained from this study would encourage counsellors and programme planners to intensify awareness campaigns on premarital genetic services among Nigerian undergraduates (Moronkola \& Fadairo, 2009).

\section{Materials and methods}

The study was a cross-sectional survey utilizing a pre-tested questionnaire (Cronbach's alpha of 0.747) to collect information about the Knowledge, Attitude and Acceptability of Premarital Genetic Services for Sickle cell disease among Babcock University undergraduates. Informed consent was sought from all the volunteer participants. Four hundred participants between the ages 15-24 were selected from students living on campus using multistage sampling technique. Questionnaires constructed were served to the participants who were required to fill the four sections.

The sample size used was drawn from the total study population by using the Cochran formula (Cochran 1963) for determining minimum sample size. Where $n=Z^{2} \mathrm{pq} / \mathrm{d}^{2}$

Where, $\mathrm{n}=$ minimum sample size; $\mathrm{Z}=$ standard normal deviation set at $1.96 ; \mathrm{p}=$ estimated prevalence of sickle cell disease in Africa averagely $25 \%$ i.e. 0.25 (WHO, 2006); $q=1-p$ (1$0.25)=0.75 ; \mathrm{d}=$ degree of accuracy desired $5 \%(0.05)$ Therefore $\mathrm{n}=(1.96)^{2} \times 0.25(0.75) /$ (0.05). Hence $n=288.12$. The minimum sample size is approximated to 300 participants. An additional 100 questionnaires was added to the minimum sample size to ensure that there is no type 1 error and to accommodate "No response".

Of the 400 questionnaires distributed, only 377 questionnaires were retrieved. The statistical analysis was done using the SPSS version 21.0 statistical software packages. The data collected were subjected to descriptive and inferential statistics using the information obtained and were summarized and presented into tables and charts and Pearson's Chi square. Knowledge scores were computed using 1 for the correct answer and 0 for the wrong answers for each of the knowledge questions on an 11- point scale. For each questions, two answers 
were available; Yes and No. The maximum score obtainable was 11 while the minimum was 0 . An addition of the knowledge score was done by adding together individual knowledge scores. The scores were then classified into two categories by taking the mean of the highest and lowest scores and a value of 7 was gotten. This was used to classify respondents into high and low levels of knowledge. Scores between 0-5.5 are low and 5.6 to 11 are a high level of knowledge. Attitude scores were computed by awarding 1 mark for each correct answer to 8 statements which assessed respondents' attitudes to premarital genetic services on a 32 point scale. For each item, there were four responses: Strongly Agree, Agree, Disagree, and Strongly Disagree. A composite attitude score was compiled by adding together the individual attitude scores. The scores were then classified into two categories by taking the mean of the highest and lowest scores and a value of 18.6499 was obtained. This was used to classify into low, average and high levels of attitude. Scores from 9-16 were low attitude and scores from 17-21 as moderate attitude and 22-30 were regarded as high attitude.

\section{Ethical consideration}

Informed consent was gotten from participants and a brief introduction of the researcher and details of the research was explained. Participants were provided voluntary participation and were free to withdraw if and when they wanted. The information obtained from the participants was treated with utmost confidentiality and an ethical clearance from was gotten from Babcock University Health and Research Ethics Committee (BUHREC) before the commencement of the research.

\section{Results}

Table 1. Socio-demographic distribution of Respondents

\begin{tabular}{lll}
\hline Characteristics & $\begin{array}{l}\text { Frequency } \\
(\mathbf{n = 3 7 7})\end{array}$ & $\begin{array}{l}\text { Percentage } \\
(\mathbf{1 0 0 \%})\end{array}$ \\
\cline { 2 - 3 } AGE & & \\
$<15$ & 6 & 1.6 \\
$16-20$ & 315 & 83.6 \\
$21-25$ & 48 & 12.7 \\
$26>$ & 9 & 2.4 \\
GENDER & & \\
Male & 148 & 39.3 \\
Female & 229 & 60.7 \\
RELIGION & & \\
Christianity & 325 & 86.2 \\
Islam & 47 & 12.5 \\
Others & 5 & 1.3 \\
\hline
\end{tabular}

As shown in table 4.1 below majority $315(83.6 \%)$ of the respondents are between the ages 16-20, while $6(1.6 \%)$ were between the 14-15 years of age with a mean age of 18.99 and S.D \pm 0.107 . Three hundred and twenty-five were Christians. Females were in the majority. 
Texila International Journal of Public Health

Volume 4, Issue 3, 2016

Table 2. Knowledge about Sickle Cell Disease and Premarital Genetic Services

\begin{tabular}{|c|c|c|c|}
\hline Variables & Categories & $\begin{array}{l}\text { Frequency } \\
(n=377)\end{array}$ & $\begin{array}{l}\text { Percentage } \\
(100 \%)\end{array}$ \\
\hline \multirow{2}{*}{$\begin{array}{l}\text { Do you know about sickle } \\
\text { cell disease? }\end{array}$} & Yes & 363 & 96.3 \\
\hline & No & 14 & 3.7 \\
\hline \multirow{3}{*}{$\begin{array}{l}\text { How can sickle cell disease } \\
\text { be transmitted? }\end{array}$} & From inheriting two abnormal & 362 & 96.3 \\
\hline & $\begin{array}{l}\text { genes "S" from your parents From } \\
\text { eating poorly }\end{array}$ & 6 & 1.6 \\
\hline & $\begin{array}{l}\text { From not using protection during } \\
\text { sexual intercourse }\end{array}$ & 8 & 2.1 \\
\hline \multirow{2}{*}{$\begin{array}{l}\text { Do you know anyone with } \\
\text { sickle cell disease? }\end{array}$} & Yes & 260 & 69 \\
\hline & No & 45 & 11.9 \\
\hline \multirow{4}{*}{$\begin{array}{l}\text { What are the symptoms of } \\
\text { sickle cell disease? }\end{array}$} & Yellowing of eyes & 197 & 52.1 \\
\hline & Swollen hands and feet & 326 & 86.5 \\
\hline & Getting sick everyday & 124 & 32.8 \\
\hline & Swollen tummy & 304 & 80.7 \\
\hline \multirow{2}{*}{$\begin{array}{l}\text { Have you heard about } \\
\text { Genotype? }\end{array}$} & Yes & 360 & 95.5 \\
\hline & No & 17 & 4.5 \\
\hline \multirow{2}{*}{$\begin{array}{l}\text { Do you know your } \\
\text { genotype? }\end{array}$} & Yes & 332 & 88.1 \\
\hline & No & 45 & 11.9 \\
\hline At what age should one & $5-12$ years & 210 & 55.7 \\
\hline \multirow{2}{*}{ know their genotype } & $13-20$ years & 147 & 39 \\
\hline & 21 and above & 20 & 3.1 \\
\hline \multirow{3}{*}{$\begin{array}{l}\text { Why should one know } \\
\text { their genotype? }\end{array}$} & For marriage & 321 & 85.2 \\
\hline & For blood transfusion & 257 & 68.2 \\
\hline & For general knowledge & 280 & 74.3 \\
\hline \multirow{2}{*}{$\begin{array}{l}\text { Have you heard about } \\
\text { premarital genetic services }\end{array}$} & Yes & 173 & 45.9 \\
\hline & No & 204 & 54.1 \\
\hline \multirow{3}{*}{$\begin{array}{l}\text { What are premarital } \\
\text { genetic services? }\end{array}$} & Services for intending couples & 159 & 91.9 \\
\hline & $\begin{array}{l}\text { marriage Activities to find out } \\
\text { your health status }\end{array}$ & 4 & 2.3 \\
\hline & & 10 & 5.8 \\
\hline Do you know where the & Yes & 105 & 60.7 \\
\hline
\end{tabular}


What are the likely centres for premarital genetic services

Sources of information about sickle cell disease
Sickle cell centre/marriage counselling

Hospital 337

Church 18

Media Friends and peers Health 275 personnel Seminar/lecturesFamily 280

Sources of information about PGS

$\begin{array}{lll}\text { Media Friends and peers Health } & 162 & 43 \\ \text { personnel Seminar/Lectures } & 36 & 9.6 \\ \text { Family } & 49 & 13 \\ & 39 & 10.4 \\ & 39 & 10.4\end{array}$

89.5

72.9

74.2

71.6

75.6

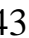

.6

10.4

10.4

As shown in Table 2, 363 (96.3\%) of respondents had heard of sickle cell disease and knew it was transmitted from inheriting two abnormal genes " $\mathrm{S}$ " from one's parents. Many, $260(69 \%)$ of the respondents knew someone with sickle cell disease.The major source of information on sickle cell was the family, $312(82.8 \%)$. Three hundred and sixty of the respondents $(95.5 \%)$ had heard about genotype, but only $332(88.1 \%)$ knew their genotypes. Three hundred and twenty-one (85.2\%) indicated marriage as the reason for knowing one's genotype. One hundred and seventy-three (45.9\%) had heard about PGS, majorly from the media, $162(43 \%)$ but only $105(60.7 \%)$ knew where these services are rendered, while 337 $(89.5 \%)$ selected the hospital as a centre for PGSs.

Table 3. Relationship status and knowledge of partners' genotype characteristics

\begin{tabular}{llll}
\hline Variables & Categories & $\begin{array}{l}\text { Frequency } \\
(\mathbf{n = 1 6 2})\end{array}$ & $\begin{array}{l}\text { Percentage } \\
(\mathbf{\%})\end{array}$ \\
\hline Are you in a relationship? & Yes & 162 & 43 \\
& No & 215 & 57 \\
How long have you been in a & $1-6$ months & 70 & 43.2 \\
relationship? & $7-12$ months & 30 & 18.5 \\
& $>1$ year & 62 & 38.3 \\
$\begin{array}{l}\text { Do you know the genotype } \\
\text { of your partner? }\end{array}$ & Yes & 110 & 67.9 \\
$\begin{array}{l}\text { What are the symptoms of } \\
\text { sickle cell disease }\end{array}$ & $\begin{array}{l}\text { Yellowing of } \\
\text { eyes }\end{array}$ & 52 & 32.1 \\
& $\begin{array}{l}\text { Swollen hands } \\
\text { and feet }\end{array}$ & 140 & 52.1 \\
& $\begin{array}{l}\text { Getting sick } \\
\text { everyday }\end{array}$ & 53.1 & 86.5 \\
& Swollen tummy & 131 & 32.8 \\
\hline
\end{tabular}

According to Table 3 on relationship status, 162 (43\%) were in a relationship. Of those who were in a relationship, $70(43.2 \%)$ had been in the relationship for 1-6 months, while 31 (18.5\%) of the respondents had been in a relationship for 7-12 months. One hundred and ten (67.9\%) of the respondents knew the genotype of their partners. Of these, 103(94\%) in total could confidently mention the partner's genotype 
Texila International Journal of Public Health

Volume 4, Issue 3, 2016

The knowledge of respondents was generally high at $7.11(\mathrm{SD}=2.1010)$ on a scale of 11 .

More than half of the respondents, 251 (66.9 \%) indicated that lack of awareness may hinder them from participating in premarital services.

Table 4. Respondents attitude towards premarital genetic services (PGS)

\begin{tabular}{|c|c|c|c|c|}
\hline Attitude towards PGS & $\begin{array}{l}\text { Strongly } \\
\text { Agree }\end{array}$ & Agree & $\begin{array}{l}\text { Strongly } \\
\text { Disagree }\end{array}$ & Disagree \\
\hline $\begin{array}{l}\text { Irrespective of the genotype of my partner, I will go } \\
\text { ahead with my relationship because all that matters } \\
\text { is love. }\end{array}$ & 5.2 & 12.8 & 49.2 & 29.7 \\
\hline $\begin{array}{l}\text { My belief does not emphasize on premarital genetic } \\
\text { service so it's not important }\end{array}$ & 4.4 & 14.1 & 44.3 & 32.6 \\
\hline I am too young to be bothered about my genotype & 3.9 & 2.6 & 60.2 & 29.9 \\
\hline $\begin{array}{l}\text { Genotype or not, God is the one who determines } \\
\text { my partner }\end{array}$ & 28.6 & 32.3 & 17.2 & 18.5 \\
\hline $\begin{array}{l}\text { All would-be- couples should undergo premarital } \\
\text { genetic services. }\end{array}$ & 60.7 & 28.4 & 3.9 & 3.1 \\
\hline $\begin{array}{l}\text { Because I and my partner hardly fall sick, we are } \\
\text { healthy and do not need to undergo any tests }\end{array}$ & 3.6 & 6.0 & 57.3 & 29.4 \\
\hline $\begin{array}{l}\text { Because of my genotype, I am at risk of having } \\
\text { children with sickle cell disease }\end{array}$ & 9.9 & 21.1 & 40.1 & 24.2 \\
\hline $\begin{array}{l}\text { Sickle cell disease is not the worst genetic disease } \\
\text { so one can live with it. }\end{array}$ & 25.5 & 39.1 & 16.1 & 16.7 \\
\hline
\end{tabular}

According to table 4 below, about 50\% disagreed to the notion that love should be the sole reason for going into marriage. Also, $44.3 \%$ did not believe religion should override the importance of PGS. 60.7\% strongly agreed that all intending couples undergo premarital genetic services. In addition, $57.3 \%$ did not believe in disregarding genetic tests irrespective of good health.

Overall the attitude of the respondents was moderate $(\mathrm{SD}=3.422$; mean $=18.65)$ on a scale of 30 . 
Table 5. Factors influencing PGS and its acceptability

\begin{tabular}{|c|c|c|c|}
\hline Variables & Categories & Frequency $(n=377)$ & Percentage $(\%)$ \\
\hline $\begin{array}{l}\text { Would you undergo } \\
\text { premarital genetic } \\
\text { services if available? }\end{array}$ & $\begin{array}{l}\text { Yes } \\
\text { No }\end{array}$ & $\begin{array}{l}350 \\
27\end{array}$ & $\begin{array}{l}92.8 \\
7.2\end{array}$ \\
\hline $\begin{array}{l}\text { Would you want } \\
\text { premarital genetic } \\
\text { services to be made } \\
\text { compulsory }\end{array}$ & $\begin{array}{l}\text { Yes } \\
\text { No }\end{array}$ & $\begin{array}{l}320 \\
57\end{array}$ & $\begin{array}{l}84.9 \\
15.1\end{array}$ \\
\hline $\begin{array}{l}\text { Reasons for } \\
\text { undergoing } \\
\text { Premarital genetic } \\
\text { counselling }\end{array}$ & $\begin{array}{l}\text { Personal belief } \\
\text { Encouragement from } \\
\text { my place of worship } \\
\text { Influence from my } \\
\text { friends and partner } \\
\text { If my family } \\
\text { encourages me to }\end{array}$ & $\begin{array}{l}307 \\
109 \\
130 \\
128\end{array}$ & $\begin{array}{l}81.5 \\
28.9 \\
\\
34.6 \\
\\
33.9\end{array}$ \\
\hline $\begin{array}{l}\text { Benefits of accepting } \\
\text { premarital genetic } \\
\text { counselling }\end{array}$ & $\begin{array}{l}\text { Awareness of } \\
\text { genotype and making } \\
\text { right choices } \\
\text { Making everyone } \\
\text { happy } \\
\text { Prevention of disease } \\
\text { in unborn child }\end{array}$ & $\begin{array}{l}271 \\
66 \\
296\end{array}$ & $\begin{array}{l}71.9 \\
17.4 \\
78.6\end{array}$ \\
\hline $\begin{array}{l}\text { Barriers to } \\
\text { participating in PGS }\end{array}$ & $\begin{array}{l}\text { Not having genetic } \\
\text { disease trait } \\
\text { Not in a relationship } \\
\text { Busy university } \\
\text { schedule } \\
\text { Lack of awareness }\end{array}$ & $\begin{array}{l}138 \\
110 \\
121 \\
251\end{array}$ & $\begin{array}{l}36.7 \\
29.2 \\
32 \\
66.7\end{array}$ \\
\hline
\end{tabular}

As shown in Table 5 above, $350(92.8 \%)$ of respondents' revealed that they would undergo premarital genetic services if it was available and $320(84.9 \%)$ would want it to be made compulsory. Three hundred and thirteen $(81.5 \%)$ of the respondents will undergo PGS due to their personal beliefs while 111(28.9\%) would undergo if their place of worship encourages them to.

The following benefits were reported by the respondents for undergoing premarital genetic services, $302(78.6 \%)$ of the respondents indicated that it is to prevent their unborn children from having genetic disease, while $67(17.4 \%)$ of the respondents indicated it is to make everyone around them happy.

Table 6. Test of Relationship between knowledge of participants and acceptability of PGS

\begin{tabular}{llll}
\hline & Value & Df & sig (2 sided) \\
\hline Pearson's Chisquare & 40.995 & 4 & 0.000 \\
\hline
\end{tabular}

$\mathbf{H}_{0}$ : there will be no significant difference between gender and knowledge of respondents on premarital genetic services for sickle cell disease

$\mathbf{H}_{1}$ : there will be a significant difference between gender and knowledge of respondents on premarital genetic services for sickle cell disease. 
Texila International Journal of Public Health

Volume 4, Issue 3, 2016

As shown in the table 5 above, at a value of $40.995, \mathrm{P}<0.05$, the null hypothesis is rejected which means that there is a significant difference between gender and knowledge. Females have a higher knowledge about premarital genetic services and sickle cell disease than the males

\section{Discussion}

\section{Knowledge about sickle cell disease and premarital genetic services?}

This research revealed that almost half of the respondents had heard about premarital genetic services (PGS) and knew about sickle cell disease. These findings are similar with studiesby Oludare et al (2013), where $80 \%$ of youths had good knowledge about sickle cell disease and premarital counselling and Olubiyi et al (2013) where 97.8\% of the participants had high knowledge about sickle cell disease. This is at variance with a study done in Jeddah where female students of Abdul-Aziz University had low level of knowledge about premarital genetic services (Ibrahim et al, 2011). This study was among unmarried females which could account for poor knowledge since they were not considering marriage and would not have sought information at the time.

Compared to the study by Olubiyi et al (2013) where about $57 \%$ of the respondents could define premarital genetic services correctly, most of the respondents could correctly state what PGS is.

\section{Attitude of respondents towards premarital genetic services}

The attitude of the respondents was fair. Very few (18\%) agreed to the notion that "love" could save a relationship threatened illness. This is contrary to the findings of Alao et al (2009) where $43 \%$ of the respondents will continue with their relationship irrespective of genetic incompatibility.

Based on the study, religious acceptability of premarital genetic services will encourage individuals to see its' importance. This is in line with the study by Nnaji et al (2013) in Nnewi where different religious institutions (Pentecostal and orthodox) mainly influenced an individual's decision to undergo premarital genetic services but in variance with Omuemu et al (2013) study in Benin where religious beliefs did notinfluence their decisions for premarital genetic services. The latter studies' findings may be as a result of the religious nature of the tertiary institutions used for this study.

\section{Relationship status and knowledge of partners' genotype}

Majority of the respondents in the study knew their genotype. Similar findings by Olubiyi et al in Ekiti State University showed a high percentage (90.3\%) of the respondents knew their genotypes. However, Alao et al (2010) recorded a lower percentage (41.2\%) who knew their partners' genotype. There are strong differences regarding knowledge of partners' genotype in different populations.

\section{Willingness to accept premarital genetic services and factors influencing acceptance}

This research study reveals that most of the respondents would undergo premarital genetic services if available. This aligns withother studies. For instance $80 \%$ of respondents, in study by Isah et al (2016) were willing to undergo premarital genetic counselling with their partners. A Similar study by Oyedele, et al, (2015) carried out in Plateau found that the majority of the respondents $(77.3 \%)$ accepted to go for premarital genotype screening. Another study by Omuemu et al amongst university undergraduates in Benin City, Edo state found that the level of acceptability of genetic screening for sickle cell disease by participants was high (96.6\%). There is therefore general acceptance of PGS and a need to include services of this nature in youth health services.

The findings of this study revealed that majority of the respondents (66.9 percent) indicated that lack of awareness may hinder them from participating in premarital genetic 
service, almost half of the respondents indicated not having a genetic trait as another factor. Busy university schedule and not being in a relationship took a slightly lower percentage. However, the two topmost reasons for not participating in PGS were "supposed healthy look" and fear of losing partners in the study by Olubiyi et al (2013). This suggests that public enlightenment on premarital genetic services is still needed to heighten people's awareness about where PGS can be located.

\section{Relationship between the knowledge and acceptability of the respondents towards premarital genetic services}

As statistically proven in the study there is a significant difference between knowledge and acceptability of respondents towards PGS. This is in line with the study by Oyedele et al (2015) in Jos where a significant difference existed between awareness and acceptability of premarital genetic services at a calculated chi square of 22.7, the null hypothesis was rejected. This may be because having a high knowledge about sickle cell disease and how it can be prevented might have increased the individuals' acceptance of the services.

\section{Conclusion and implications for public health practice}

In this study, very few respondents had heard about premarital genetic services as compared with knowledge about sickle cell disease. It confirms the gap existing between classroom knowledge and access to services. Premarital counseling is one of the most important strategies for prevention of genetic disorders, congenital anomalies, and several medical psychosocial marital problemsThus, premarital counseling service should be a very strong health promotion tool for preventing diseases and increasing the quality of life. School health services have a role to playin bridging the gap between knowledge and practice especially as some relationships which begin in the university end up in marriage unions. This can safeguard the health of future generations.

\section{Recommendations}

Comprehensive sexuality education helps youths assume responsibility for life-long sexual health by providing medically accurate information and enhancing decision-making skills at a crucial developmental stage. Thus, PGS should be incorporated intoschools' curriculum involving all age and department categories with special focus on students. Also Youth Friendly services should incorporate services of this kind into their programmes.

\section{References}

[1]. Alao, O.O., Araoye, M., \& Ojabo, C. (2009). Knowledge of sickle cell disease and haemoglobin electrophoresis: a survey of students of a tertiary institution. Nigerian Journal of Medicine, 18(3), 3269. Retrieved from http://www.ncbi.nlm.nih.gov/pubmed/20120655

[2]. Al-Khaldi, Y. M., Al-Sharif, A. I., Sadiq, A. A., \& Ziady, H. H. (2002). Attitudes to premarital counseling among students of Abha Health Sciences College. Saudi Medical Journal, (8), 986-990. Retrieved

from https://www.researchgate.net/publication/11156130_Attitudes_to_premarital_counseling_among_stude nts_of_Abha_Health_Sciences_College

[3]. Anie, K. A., Egunjobi, F. E., Akinyanju, O. O. (2010). Psychosocial impact of sickle cell disorder: Perspectives from a Nigerian setting. Globalization and Health, 6(2). DOI: 10.1186/17448603-6-2

[4]. Diallo, D., \& Tchernia, G. (2002) Sickle cell disease in Africa. Current Opinion in Hematology, 9, 111-116. Retrieved from http://www.ncbi.nlm.nih.gov/pubmed/11844993

[5]. Ibrahim, N.K.R., Al-Bar, H., Al-Fakeeh, A., Al-Ahmadi, J., Qadi, M., Al-Bar A., \& Milaat, W. (2011). An educational programme about pre-marital screening for unmarried female students in King Abdul-Aziz University, Jeddah. Journal of Infection and Public Health, 4(1), 30-40. DOI: http://dx.doi.org/10.1016/j.jiph.2010.11.001 
Texila International Journal of Public Health

Volume 4, Issue 3, 2016

[6]. Isah, B. A., Musa, Y., Mohammed, U. K, Ibrahim, M. T. O., Awosan, K. J.,\& Yunusa, E. U.(2016). Knowledge and Attitude Regarding Premarital Screening for Sickle Cell Disease among Students of State School of Nursing, Sokoto. Annals of Internal Medicine, 2(3), 29-34. DOI: 10.21276/aimdr.2016.2.3.9

[7]. Ministry of Health Portal Kingdom of Saudi Arabia. (2014). Overview of Premarital Screening. Retrieved from http://www.moh.gov.sa/en/HealthAwareness/Beforemarriage/Pages/default.aspx

[8]. Moronkola, O. A., \& Fadairo, R. A. (2007). University students in Nigeria: Knowledge and attitude toward sickle cell disease, and genetic counseling before marriage. International Quarterly of Community Health Education, 26(1), 85-93. DOI: 10.2190/JN25-4353-75PK-3733

[9]. Nnaji, G. A., Ezeagwuna, D. A., Nnaji, I. J. F., Osakwe, J. A. (2013). Prevalence and Pattern of Sickle Cell Disease in Premarital Couples in South Eastern Nigeria. Nigerian Journal of Clinical Practice, 16(3), 309-314.Doi: 10.4103/1119-3077.113452.

[10]. Olubiyi, S. K., Umar, J. N., Ajiboye, O., Olubiyi, V. M., Abioye, T. A. S. (2013). Knowledge and attitude of undergraduates of Ekiti State University towards sickle cell disease and genetic counselling before marriage Sky Journal of Medicine and Medical Sciences 1(7): 29 - 35. Retrieved from http://www.skyjournals.org/sjmms/pdf/2013pdf/Nov/Olubiyi\%20et\%20al\%20pdf.pdf

[11]. Oludare, G.O., \& Ogili, M. C. (2013). Knowledge, Attitude and Practice of Premarital Counseling for Sickle Cell Disease among Youth in Yaba, Nigeria. African Journal of Reproductive Health, 17(4): 175 - 182. Retrieved from http://www.bioline.org.br/pdf?rh13067

[12]. Omuemu, V. O., Obarisiagbon, O. E.,\& Ogboghodo, E. O.(2013) Awareness and acceptability of premarital screening of sickle cell disease among undergraduate students of the University of Benin, Benin City, Edo State. Journal of Medicine and Biomedical Research; 12 (1), 91 - 104. Retrieved from http://www.ajol.info/index.php/jmbr/article/view/91817

[13]. Oyedele, E. A, Emmanuel, A., Gaji, L. D., Ahure, D. E. (2015). Awareness and acceptance of premarital genotype Screening among youths in a Nigerian community. International Journal of Medical and Health Research, 1(1), 17-21. Retrieved from

http://irepos.unijos.edu.ng/jspui/bitstream/123456789/992/1/1-1-30.pdf

[14]. Owolabi, R. S, Alabi, P., Olusoji, D., Ajayi, S., Otu, T., \& Ogundiran, A. (2011). Knowledge and attitude of secondary school students in Federal Capital Territory (FCT), Abuja, Nigeria towards sickle cell disease. Nigerian Journal of Medicine, 20(4), 479-485. Retrieved from http://www.ncbi.nlm.nih.gov/pubmed/22288328

[15]. Piel, F. B., Hay, S. I., Gupta, S., Weatherall, D. J., \&Williams, T. N. (2013) Global Burden of Sickle Cell Anaemia in Children under Five, 2010-2050: Modelling Based on Demographics, Excess Mortality, and Interventions. Retrieved from

http://journals.plos.org/plosmedicine/article?id=10.1371/journal.pmed.1001484

[16]. Tamhankar, P. M., Agarwal, S., Arya, V., Kumar, R., Gupta, U. R., \& Agarwal, S. S. (2009). Prevention of homozygous beta b-thalassemia by premarital screening and prenatal diagnosis in India. Prenatal Diagnosis, 29(1), 83-8.doi: 10.1002/pd.2176.

[17]. World Health Organization. (2006) Sickle-cell anaemia: Report by the Secretariat. Provisional agenda item 11.4 for the Fifty- Ninth World Health Assembly held on 26th April. Geneva. WHO. A59/9: 1 - 5. Retrieved from http://apps.who.int/gb/ebwha/pdf_files/WHA59-REC3/WHA59_REC3en.pdf

[18]. World Health Organisation. (2011). The Brazzaville declaration on Non-communicable diseases prevention and control in the WHO African region. Retrieved from http://www.who.int/nmh/events/2011/ncds_brazzaville_declaration.pdf 